Banko Janakari, Special Issue No. 4

\title{
Silviculture for forest management in Nepal
}

\author{
K. C. Poudel ${ }^{1}$
}

Forests and trees have social, ecological and economic importance to humankind. It is high time to manage worlds' forests sustainably to ensure supply of forest based goods and services and reduce the adverse impacts of climate change. This paper highlights the history and current status of forest management, challenges and opportunities, various approaches adopted in forest management and recent initiatives in sustainable and scientific forest management (SFM) in Nepal. About one-third of the total 6.61 million ha (45\%) of Nepal's forest has been handed over to over 30,000 forest user groups. Various failed attempts in forest management in the past were mainly due to lack of institutional capacity, political back-up, conflict, etc. "Forestry for Prosperity" - a new vision announced at the 10th National Conservation Day in 2012, re-introduced the concept of sustainable and scientific forest management and launched this in ten districts with designated program and budget in the same year. Accordingly, forest blocks are identified, inventoried, management plans drawn and implemented. Over 69, 000 ha forests in 11 districts are under silviculture management to date. Thus managed forests show profuse regeneration, improved supply of forest products, increased revenue, improved forest health and enhanced capacity of forestry professionals. Yet, lack of political and professional commitment, inadequate human and financial resources, and weak institutional and professional competency are specific challenges to SFM in Nepal. Creating enabling environment, institutional reorganization, enhancing forest management capacity, improved forestry governance, reducing non-forestry workload of government forestry staff, and preparation and use of standard silvicultural operational guidelines have been suggested to upscale SFM in Nepal.

Key words: Forest management, Nepal, prosperity, silviculture

F orests and trees have social, ecological and economic importance throughout the world since the beginning of human civilization. They provide various goods and services to mankind and contribute in food security, energy, health, culture, tourism, biodiversity conservation and climate regulation. Forest ecosystems have potential to reduce poverty, enhance economic growth and prosperity thereby contributing to sustainable development. To date forests are getting higher attention globally due to their capacity to minimize impacts of climate change as trees absorb $\mathrm{CO}_{2}$ during photosynthesis and turn it into solid carbon and store in their trunk, bark, leaves and roots and contribute in reducing $\mathrm{CO}_{2}$ emission. However, natural forests are disappearing at a faster rate than ever before due to human induced pressures such as deforestation, degradation, forest fire, urbanization, agriculture

1. Former Secretary, Ministry of Forests and Soil Conservationse email:kcpoudel@gmail.com expansion and also due to climate change impacts. In such a situation, it is high time to manage world's forest sustainably, using science based silvicultural practices for sustained production and supply of forest products and ecosystem services. This paper describes history of forest management in Nepal, recent initiatives, objectives of sustainable and scientific forest management (SFM), various approaches, initial results, challenges and way forward to upscale SFM in Nepal.

\section{Nepalese forests and their management status to date}

Nearly $45 \%$ of land mass (6.61 million ha) in Nepal is covered with forest including other wooded land (DFRS, 2015). Most of the accessible forests are handed over and managed under different categories (community forests, 
collaborative forests, leased forest) for multiple use, mostly under adaptive management by local communities, called forest users. Government of Nepal has handed over about one-third of the total forest area to over 30,000 forest user groups. However, only about 69,000 ha of forests in 11 districts are under active forest management to date.

As a result of massive community mobilization and their willing in participation in forest conservation and domestic use over the past three decades, forests in the middle mountains and high mountains have increased in terms of area and quality (DFRS, 2015). But during the same period, forests in Chure foot hills, Siwaliks and in Tarai continued to degrade due to serious challenges such as forest land encroachment, forest fire, over grazing, over exploitation, etc. Despite of invaluable contribution to sustain food, water and energy systems, forestry sector has never been considered as high priority sector by the government in terms of resource allocation. It remained rather blamed for less paying in the government treasury and environmental over concerned and hurdle for various kinds of resettlement schemes and development of physical infrastructures by so called power producers, miners/extractors and other physical infrastructure developers.

Rural households are still heavily dependent on forest resources for energy (64\%), timber and non-timber forest products for construction and livelihoods. Supply of major forest products is dominated by private and community production, mostly locally and informally. Market price of construction timber in cities is unregulated, often distorted and increasing at a level unaffordable by general public. Import of timber is increasing. In the past and even today in Tarai, most of the forestry officials are bound to engage in policing, patrolling, fighting against forest land encroachment, revenue collection and judiciary activities.

Many attempts were made in the past by various institutions for silvicultural management of Nepal's forests. The Finland aided Forest Management and Utilization Project (FMUD), which worked in Tarai, was one of them but failed due to various reasons such as lack of institutional capacity, political back-up and conflict of interests among stakeholders. Felling of green trees was banned in Nepal because of mismanagement, over-harvesting, theft and exploitation of forests. Oversight agencies often put a ceiling on harvesting the annual increment to regulate forest harvest and establish governance. In absence of scientific management of forests in the past, some forests, mostly in the inaccessible areas are over matured, quality of timber is sacrificed while others are over exploited leading to forest degradation. Large plantations of Pines in the hills of central development region are not even thinned on time. Hence, the composition, age distribution, health and productivity of forests have been compromised and deviated from normal forest concept.

As government forestry institutions are old and historically least oriented towards SFM, it lagged behind by over a quarter of a century even after the Master Plan for Forestry Sector (MPFS) was approved by the government in 1989 (MPFS, 1989).. Therefore, it is high time that forestry professionals are made more responsible, reoriented and motivated towards SFM, forestry institutions are reorganized and the foresters' job description be revisited to suit present context for tackling growing problems and exploit the potentials.

\section{Recent initiatives in scientific forest management}

Realizing the urgent need for sustainable management of Nepal's forest and recognizing the huge potential for the prosperity through forestry, a new vision on forestry - "Forestry for Prosperity" was announced by the author in then capacity of Secretary of Ministry of Forests and Soil Conservation at the auspices of the 10th National Conservation Day on 23rd Sep. 2012. The vision contained four major pillars of prosperity - Sustainable and scientific forest management, Sustainable use of forest products and services, Commercialization and marketing of forest resources and creating enabling environment (Fig. 1). The vision was shared among wider stakeholders nationally and internationally. Taking feedback from various experts and stakeholders, it was refined and approved by the Ministry in January 2012 (MoFSC, 2012). Based on this vision a new forest policy was endorsed by the Government of Nepal (GoN) in 2015. As 
a new beginning in 2012, at least one forest each in 10 districts including Kapilvastu, Nawalparasi, Morang, Kailali were selected for scientific forest management with special budgetary support from then Multi-stakeholder Forestry Program. Since then, the Scientific Forest Management (SFM, often used as sustainable forest management interchangeably) has been internalized and mainstreamed under the regular annual program of the Forest Department. This vision has also been incorporated in the 14th periodic plan developed by the National Planning Commission.

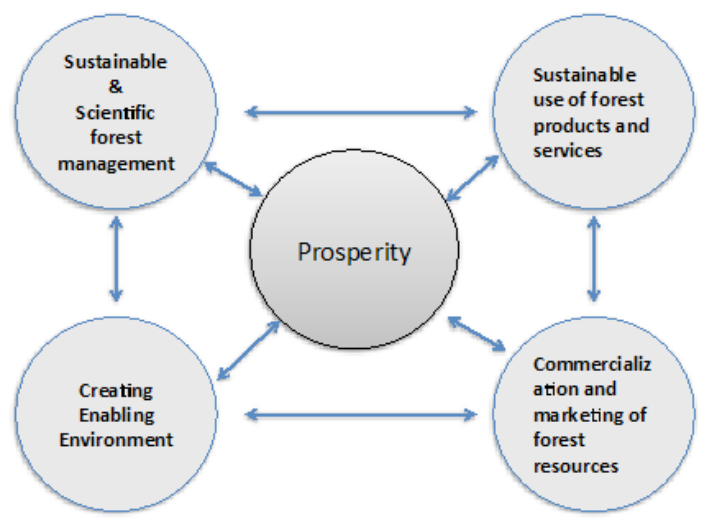

Fig. 1: Four pillars of the vision -"Forestry for Prosperity" and their linkages

Currently, SFM program is implemented in degraded Sal and mixed hardwood forests of Tarai region. Other forest types include planted Eucalypts, Teak and Sissoo in Sagarnath area. SFM initiatives are implemented in collaboration with local community and collaborative forest users, very few blocks of government managed forests are included. This has reduced the cost of operations and raised awareness and confidence of stakeholders in application of silvicultural principles, mostly green felling and natural regeneration. Silvicultural systems applied include mainly irregular shelter wood system followed by simple coppice, coppice with standard and selection system. Although there are no evidence based prescribed rules and procedures on SFM in Nepalese context, the learning by doing approach, follows following steps:

I. Identification and /or selection of forest for SFM

II. Stakeholder consultation

III. Survey, mapping and separation into block/compartments
IV. Forest inventory

V. Preparation of management plan with defined activities and time

VI. Implementation of management plan/ forest operations

VII. Benefit sharing among stakeholders

Some of the key features of SFM as practiced in Nepal to date include intensive forest inventory (100\% trees measured), measurement of $\mathrm{CO}_{2}$ stock, selection of mother trees, rotation of Sal is fixed at 80 years and working period of 10 years. However, choice of silviculture system and yield regulation is not uniform due to disproportionate age- class distribution of degraded forest that created complexity in yield regulation. Some ambiguity in understanding silvicultural systems and inconsistencies in the use of silvicultural terms has also been noticed.

Observation to some of the SFM plots indicates that the forest inventory as carried out is intense and expensive, $100 \%$ enumeration of trees (both to be retained or felled ) using GPS in each compartment is neither affordable nor necessary. Such practice is to make the process more transparent and to avoid any potential blames by media and oversight agencies - a situation lacking trust and confidence in scientific forest management. Despite adequate technical knowhow and physical facilities, efforts on removal of over mature trees and regeneration has been appreciating. Regeneration of Sal has been successful both naturally and by direct sowing.

Scientifically managed forests, in short period, have demonstrated following results:

- Profuse natural regeneration

- Improved forest condition

- Increment of growing stock

- Revenue generation higher than investment

- Impressive training and demonstration sites

- Growing interest about and better understanding of SFM

- "Forestry for Prosperity" has become common vision for all.

- Few foresters championing on SFM 


\section{Objectives of SFM Nepal}

Considering the condition of forests, need of local communities, available resources for forestry operation and professional competency, the SFM intervention in Nepal should, inter alia, meet following objectives, where applicable:

- Removal of over mature trees to meet the current demand of timber and firewood and encourage natural regeneration,

- Increase production and productivity considering domestic demand and commercialization potential of forests for prosperity,

- Maintain/improve appropriate species composition and age distribution,

- Maintain forest biodiversity to meet the demand of multiple goods and services of indigenous and local communities,

- Preservation of sites, habitat and species of historic, religious, cultural and aesthetic value

- Maintain ecosystem services,

- Reduce disaster risks and minimize climate change impacts and,

- Create green jobs and enterprises for socio economic development

In order to achieve the broader national goal of prosperity through SFM, appropriate silvicultural systems should be identified, customized if needed and applied for desired results. Hence, choice of appropriate silviculture system for SFM should meet the objectives of forest management as mentioned above and also consider the following criteria:

- Silviculture systems must be based on scientific principles, simple to understand and easy to apply by mid level technicians and forest users

- Identification and use of simple and cost effective survey, inventory, mapping, yield regulation methods

- Use of efficient/appropriate harvesting, transportation, fire fighting tools and machines where applicable (consider availability of skilled forest workers)
- Silvicultural characteristic of the species (light demander/shade bearer, etc.)

- $\quad$ Forest type (broadleaves, conifer, etc. )

- Condition of the forest (degraded, well stocked, plantations, regeneration, etc.)

- Composition of forest (pure Sal or Sal mixed hardwoods, associated spp., etc.)

- Development stage (regeneration/new plantations, pole, mature, over mature, etc )

- Objective of forest management (timber, pole production, other NTFPs, etc.)

- Topography of the forest (terrain, accessibility)

- Management objectives and size of forests

\section{Challenges to application of silvicultural principles in forest management}

Nepal is a country of numerous challenges and opportunities in terms of forest resource. Forests are interlinked with agriculture, tourism, industries, water resource, energy and environment in one hand and it is a single such natural resource that embraces over one-third of the total Nepalese households in its management and use on the other. Forestry is not therefore only an ecological business but also a strong socio-political agenda of its diverse stakeholders and balancing conflicting interest of diverse stakeholders is a major challenge. Likewise, in the new political system, benefit sharing among central, provincial and local government could be challenging due to disproportionate distribution of forests in different provinces. It may lead to conflict unless an agreeable mechanism for balancing demand and supply of forest product and services is devised and forestry sector governance is significantly improved on time. However, new avenues for prosperity should not be undermined under smooth political transition scenario.

Among many challenges that forestry sector faces to date, some of the specific challenges for the successful implementation of silvicultural management, inter alia, include:

- Lack of political and professional commitment,

- Inadequate and inefficient human resource, 
- Weak institutional and professional capacity,

- Lack of adequate technical knowledge, skills, orientation, motivation and basic physical facilities (office space, accommodation, transportation) to field foresters, and

- Low priority and inadequate resource allocation to SFM

\section{Way forward to upscale SFM}

First and foremost condition to nurture and upscale SFM in Nepal to date is to create an enabling environment towards SFM. Entry point may be establishment of a core group of Silviculturists within the Forest Department and build their capacity together with the capacity of the Department itself. This may include a human resource development plan, education and training, exposure visit, orientation and reorientation of front line forest staff. Raising awareness, motivation and demonstration to forestry sector stakeholders and forest owners including community and collaborative forest users, local government bodies is equally essential. The core group of silviculturists once established could then be trained, motivated and used as resource persons and catalyzer for training and capacity building of others for faster up-scaling of the SFM. Separate career path should be developed to encourage and use their expertise and prevent them from unwanted political and bureaucratic harassment, such a group of silviculturists should only be transferred within the territories of similar task.

Secondly, institutional reorganization in the federalized context is urgent. This may include strengthening silviculture wing of the Department of Forests and expanding in all Regions/ Provinces, also strengthening of stakeholder/ local community institutions and enhancing their forest management capacity is equally important.

Thirdly, reducing non forestry related work load (policing, patrolling, revenue collection and judiciary function) of forestry professionals and focusing their role in scientific research and core forestry are essential. Forests as national and public property, designated specialized agencies for the protection of such property (e.g. Nepal Police, Armed Police Force, etc.) should be made responsible for the policing, patrolling, fighting against forest theft and encroachment of forest lands. Likewise, forestry professionals should be relieved from the sales of forest products except at the stumpage. It can be better done by other specialized agencies responsible for commerce and supplies or by a private sector in the free market economy. This will in one hand reduce unhealthy competition for transfer of officials at certain districts and on the other, save time to focus on core forestry function. As per new constitution, implementation of Forest Law and judiciary function of the DFO should be handled by the respective agencies.

Fourth, Establishment and strengthening a robust information system to make all forestry transactions, operations, inventory records and stock piles of forest products is essential to build trust and make forestry profession more transparent, reliable and predictable. All the information of public interest such as forest management plans, inventory records, growing stock, stock of timber, fire wood and other forest products and sales and purchase records at various districts offices and also in the community/ collaborative forests should be made clearly visible and transparent to assure good forest governance to general public.

Fifth, forestry being a long rotational business, identification, establishment and continuity of long-term scientific research to better understand the response of various silvicultural systems and management regimes, including that of the human and climate change induced factors have to be carefully planned and monitored in collaboration with academia and relevant national, regional and international forestry research organizations.

Sixth, in order to translate scientific principles of forest management into practice, sound guidelines and operational procedures must be developed and communicated. Based on available information and gained experience over few years, the SFM guidelines should be revised and updated. A matrix as a decision making tool for the choice of silvicultural system may be developed, field tested and recommended to suit diverse forest types and management regimes for the simplicity and uniformity. Forests must be managed based on scientific principles, not as directed by oversight agencies. Increment and allowable cuts must be removed for optimum production using sound silvicultural systems without hesitation. 
Finally, investment in forest management must be increased. Provision of forest insurance, community/collaborative forests as collateral to get soft loans, provision of small forest management grants and provision of loans at low interest rate (as for agriculture) may encourage forest owners and private sector to invest more on SFM for higher yield and for the healthy future crop.

Last but not the least, serious commitment on collective and continuous efforts among forest policy makers, professionals and stakeholders is essential to gear up scientific/sustainable forest management in Nepal.

\section{References}

DFRS, 2015. State of Nepal's Forests. Forest Resource Assessment (FRA) Nepal, Department of Forest Research and Survey (DFRS). Kathmandu, Nepal.
MPFS, 1989. Master Plan for Forestry Sector Nepal. Government of Nepal, Ministry of Forests and Soil Conservation, Kathmandu, Nepal.

MoFSC, 2012. "Forestry for Prosperity 2012". A government of Nepal's official document endorsed by the Minister for Forest and Soil Conservation, Kathmandu, Nepal.

GoN, 2015. Forest Policy 2071 BS. Government of Nepal (GoN) Ministry of Forests and Soil Conservation, Kathmandu, Nepal. 